\title{
Acción de gracias
}

\author{
Juan Noemi*
}

Gracias Señor por los... años de vida que me regalaste.

Gracias por ese Amor -en que aconteces Tú mismo- con el cual se amaron mis padres y del que soy fruto.

Gracias por nacer en un valle en medio del desierto.

Gracias por la ternura con que me acogiste en la sombra de los árboles y el aroma del romero, la albahaca y las madreselvas.

Gracias por mostrarme lo fundamental de tu misterio en la aridez del desierto, el azul del mar y el pestañar de las estrellas.

A ti te bendicen todos los pájaros que miré cuando niño.

Gracias por las palabras que aprendí en Freirina, Santiago, Roma y Münster.

Bendice a todos mis maestros. Gracias Señor por la música del viento en los eucaliptus y también por la de Bach y Schostakovich.

\footnotetext{
* El profesor Juan Noemi escribió esta oración de acción de gracias que fue leida por su hijo Daniel en su funeral.
}

Gracias por los colores: el ocre del desierto, el anaranjado de Roma y también los de Matisse y Gordon. Gracias porque hiciste de $\mathrm{mi}$ encuentro con Flú la aventura de mi vida que se prolongó en más vida: gracias por Daniel y David. Bendícelos con toda la ternura de tu amor.

Gracias por mis hermanas y hermanos, amigas y amigos, colegas $\mathrm{y}$ alumnos. A ti te bendicen todos ellos con el bien que me han hecho. Gracias, sobre todo, Señor por la fe que me regalaste en Jesús, que me da la certeza de que tu Amor es más decisivo que mi pecado, y que por ese mismo Amor ahora me rescatas de la muerte.

A ti, Amor insondable, Padre, Hijo, Espíritu, a Ti te doy gracias por mi vida en la hora de mi muerte. A ti el honor y la gloria por siempre. 
